\title{
Peran Guru Pkn Dalam Model Pengajaran Advokasi Untuk Meningkatkan Pemahaman Isu-Isu Sosial Pada Siswa
}

\author{
Nurwahidah', Zedi Muttaqin²
}

${ }^{1}$ Pendidikan Pancasila dan Kewarganegaraan, Universitas Muhammadiyah Mataram, nurwahidah17@gmail.com
${ }^{2}$ Pendidikan Pancasila dan Kewarganegaraan, Universitas Muhammadiyah Mataram, zedi.muttaqin@gmail.com

INFO ARTIKEL
Riwayat Artikel:
Diterima: $\quad$ 17-Agustus-
2018
Disetujui: 17-September-
2018

\section{Kata Kunci:}

peran

guru

pengajaran

advokasi

pemahaman

isu

sosial

\section{A. LATAR BELAKANG}

Undang-undang No. 20 Tahun 2003 Tentang Sisdiknas yakni pendidikan adalah usaha sadar dan terencana untuk mewujudkan suasana belajar dan proses pembelajaran agar peserta didik secara aktif mengembangkan potensi dirinya untuk memiliki kekuatan spiritual keagamaan, pengendalian diri, kepribadian, kecerdasan, akhlak mulia, serta keterampilan yang diperlukan dirinya, masyarakat, bangsa dan negara.

Menurut Undang-undang Nomor 20 tahun 2003 tentang Sisdiknas, pembelajaran adalah serangkaian

\section{ABSTRAK}

\begin{abstract}
Abstrak: Siswa MTs Nahdlatul Mujahidin NW Jempong kebanyakan memiliki sifat mudah diatur, dan aktif dalam tanyajawab. Namun, saat pembelajaran siswa sering bercanda dengan teman hanya beberapa yang memperhatikan materi yang disampaikan, dan beberapa siswa justru tidak menghiraukan walaupun sudah dinasehati dengan baik. Hal ini uga yang menyebabkan siswa belum mampu memahami materi tentang isu-isu sosial seperti: Kemiskinan, bencana alam, korupsi, pembunuhan dan lain-lain. Metode penelitian ini menggunakan metode kualitatif dengan pendekatan deskriptif, tehnik penentuan subjek observasi, wawancara dan dokumentasi, analisis data yang digunakan adalah reduksi data, penyajian data dan kesimpulan atau verifikasi data. Hasil penelitian menunjukkan bahwa guru PKn dalam mengajar mengutamakan membina sikap sesuai nilai-nilai pancasila, melakukan pendekatan emosional. Memberi contoh perilaku teladan yang baik, melakukan penilaian sikap, memberikan motivasi, atau nasehat, rutin melakukan kegiatan sosial dan keagamaaan, seperti sholat duha, sholat dzuhur dan sholawatan/ yasinan setiap jum, at serta aktif dalam kegiatan hari besar keagamaan islam lainnya, pembinaan sikap juga melalui upacara bendera dengan memberi motifasi dan nasehat dan sikap siswa.
\end{abstract}

\begin{abstract}
Students of MTs Nahdlatul Mujahidin NW Jempong mostly have the nature to be arranged, and active in the ask. However, when learning students often joke with friends only a few are concerned about the material being delivered, and some students just ignore it even though it is advised well. It also causes students not to be able to understand the material about social issues such as poverty, natural disasters, corruption, murder, and others. This method of study uses qualitative methods with a descriptive approach, the technique of determining the subject of this study using purposive sampling with data collection techniques such as observation, interviews and documentation, data analysis Used are data reduction, data presentation, and conclusion or data verification. The results showed that PKn teachers in teaching prioritize to cultivate attitudes according to the values of Pancasila, an emotional approach. Exemplified good example behavior, familiarizing coming on time, discipline, nurturing students doing group learning, doing attitude assessment, giving motivation, or advice, routine social and religious activities, such as Duha prayers, Praying Dhuhr and who visit/Yasinan every Fri, at and active in other Islamic religious day activities, the development of attitudes also through the flag ceremony by giving motives and advice and attitude of students.
\end{abstract}

kegiatan yang dirancang untuk memungkinkan terjadinya proses belajar pada siswa. Proses interaksi peserta didik dengan pendidik dan sumber belajar pada suatu lingkingan belajar. Ciri utama dari pembelajaran adalah inisiasi, fasilitasi, dan peningkatan proses belajar siswa tujuan, materi, kegiatan, dalam konteks pembelajaran yang dilakukan guru,maka guru dituntut untuk dapat mengelola pembelajaran (learning management).

Undang-undang Guru dan Dosen adalah UndangUndang Nomor 14 tahun 2005 tentang guru dan dosen. Pada UU No 14 Tahun 2005. Guru adalah pendidik profesional dengan tugasutama mendidik, mengajar, 
membimbing, mengarahkan, melatih, menilai, dan mengevaluasi peserta didik pada pendidikan formal dan pendidikan menengah, sedangkan Dosen adalah pendidik profesional dan ilmuwan dengan tugas utama mentransformasikan, mengembangkan dan menyebarluaskan ilmu pengetahuan melalui pendidikan, penelitian, dan pengabdian kepada masyarakat.

Di dunia pendidikan ketercapaian tujuan pembelajaran sangat ditentukan oleh guru, kurikulum, dan perangkat-perangkat yang digunakan guru dalam mengajar. Selain itu potensi dan semangat siswa untuk belajar juga menentukkan. Pada kegiatan belajarmengajar guru menyampaikan materi biasanya dengan teknik, metode, dan model-model tertentu. Semakin banyaknya model-model Pembelajaran di dunia pendidikan, akan tetapi lebih pada prakteknya masih banyak tenaga pendidikan yang menggunakan model pembelajaran yang klasikal yang berpusat pada guru (teacher centered)[1]. Terjadi peningkatan ketuntasan klasikal siswa yaitu pada siklus I 66\% dan pada siklus II sebesar 88\%, sehingga dapat disimpulkan bahwa penerapan model pembelajaran Treffinger dapat meningkatkan aktivitas dan prestasi belajar siswa PKn kelas VIII SMP[2]. Hal tersebut menunjukkan bahwa penggunaan metode tertentu pada proses belajarmengajar mampu maningkatkan aktivitas dan prestasi belajar siswa. Hasil penelitian selanjutnya menunjukkan diperoleh thitung 0,146 dan $t_{\text {tabel }}$ 2,02dengan taraf signifikan $0,05 \%$ sehingga $t_{\text {itung }}>t_{\text {tabel }}$, maka hipotesis Ho diterima dan $\mathrm{Ha}$ ditolak, sehingga dapat disimpulkan bahwa siswa yang belajar dengan model pembelajaran Student Facilitator And Explining (SFAE) tidak memiliki pengaruh dari siswa yang belajar dengan model pembelajaran konvesional. Maka hipotesis Ho berbunyi "Tidak terdapat pengaruh model pembelajaran Student Facilitator And Explining (SFAE) terhadap hasil belajar siswa[3].

Hasil observasi ada berbagai kendala yang dijumpai, meskipun secara umum berjalan dengan lancar, tetapi masih ada beberapa hal yang menjadi penghambat dalam keberhasilan proses pengajaran. Adapun hambatan yang dialami pengajar saat melakukan proses pengajaran adalah berkaitan dengan kondisi sarana dan prasarana dimana ada tersedianya LCD tapi hanya berpatokan hanya pada LKS. Siswa MTs Nahdlatul Mujahidin NW Jempong kebanyakan memiliki sifat mudah diatur, dan aktif dalam tanyajawab. Saat pembelajaran, siswa sering bercanda dengan teman hanya beberapa yang memperhatikan materi yang disampaikan, dan sebagian siswa yang sama sekali tidak menghiraukan walaupun sudah dinasehati dengan baik. Selain itu, siswa juga belum memahami materi-materi terutama tentang isu-isu sosial seperti: Kemiskinan, bencana alam, korupsi, pembunuhan dan lain-lain. Akibatnya proses pembelajaran yang dilaksanakan oleh guru belum berperan dalam mengembangkan potensi peserta didik secara optimal[1].
Berdasarkan masalah di atas perlu dicarikan solusinya. Solusi yang paling efektif adalah untuk meningkatkan pemahaman isu-isu social adalah menggunakan model pembelajaran advokasi. Model ini menuntut para siswa fokus pada topik yang telah ditentukan sebelumnya yang dianggap penting sebaiknya, topik yang diperdebatkan adalah isu-isu yang sesuai dengan minat dan kebutuhan siswa. Untuk memenuhi kebutuhan yang spesifik guru dapat saja menunjuk suatu kelompok siswa untuk menyajikan debat di kelas dan mengajukan pendapat tersebut. Belajar advokasi menuntut siswa menjadi advokat dari pendapat tertentu dengan topik yang tersedia.

Terkait dengan hal tersebut beberapa pendapat menjelaskan bahwa model pembelajaran Advokasi dapat meningkatkan hasil belajar IPS pada siswa kelas III SDN Bendo 2 Kecamatan Kepanjen Kidul Kota Blitar dengan baik. Untuk itu disarankan bagi guru sebagai seorang ahli yang mampu merancang dan melaksanakan pembelajaran dengan interaksi yang edukatif, komunikatif yang menyenangkan bagi siswa dan guru sendiri[4].

Demikian juga pendapat lain menyatakan bahwa pembelajaran dengan pendekatan Advokasi dengan penyajian masalah Open-ended memberikan pengaruh konsisten dibandingkan dengan pengaruh pembelajaran konvensional. Selain itu, penelitian juga menemukan: (1) tidak terdapat interaksi antara pembelajaran pendekatan Advokasi dengan penyajian masalah Open-ended dan pengetahuan awal matematis siswa (PAM) terhadap kemampuan koneksi matematis siswa. (2) terdapatasosiasi antara kemampuan koneksi matematis siswa dan hasil belajar siswa[5].

Pembelajaran model advokasi menekankan pada aspek keterampilan riset, keterampilan analisis, dan keterampilan berbicara, dan mendengar, sebagaimana mereka berpartisipasi aktif dalam pembelajaran advokasi di dalam maupun di luar kelas melalui pengalaman sebelumnya terkait masalah pembelajaran advokasi, siswa tentu dihadapkan pada kontroversial dan harus mengembangkan suatu kasus untuk mendukung pendapat siswa di dalam kelas melalui pembelajaran advokasi itu sendiri, melalui perangkat dan petunjuk dan tujuan-tujuan khusus yang berkaitan dengan pembelajaran advokasi[6].

Jadi pembelajaran advokasi, para siswa berpartisipasi dalam suatu debat antara kelompok regu, yang masingmasing terdiri dari dua orang siswa. setiap regu memperdebatkan topik yang berbeda dari para anggota kelas lainnya. Karena itu, di dalam suatu kelas yang terdiri dari 23 orang siswa akan memperdebatkan 8 buah topik.

Berkaitan dengan proses advokasi sosial terbagi menjadi delapan kategori, yaitu (1) Analisisis makro, (2) Penentuan tujuan advokasi, (3) Definisi masalah dan membingkai isu (4) Identifikasi dan analisis stakeholder, (5) Pelaksanaan strategi dan taktik (6) Membuat 
perjanjian (7) kendala dalam advokasi (8) Evaluasi advokasi. Sementara itu, hasil penelitian menunjukan bahwa model advokasi sosial terbagi menjadi lima kategori, yaitu (1) perencanaan (2) pelaksanaan (3) observasi (4) Evaluasi dan (5) refleksi[7].

Pengajaran advokasi merupakan salah satu pembelajaran yang paling efektif untuk melahirkan generasi yang memiliki pandangan untuk dapat menjadikan pembelajaran ini yang konsentrasi pada masalah perdebatan di dalam kelas tersebut. Sebagai bagian yang harus diapresiasi secara konstruktif. Pemahaman dan kesadaran terhadap guru dan siswa di MTs Nahdlatul Mujahidin NW Jempong realitas tentunya akan memiliki dampak yang konkrit dalam proses pembelajaran berdasarkan pengajaran serta pemahaman guru serta siswa di dalam pengajaran advokasi di kelas VIII secara luas di masa yang akan datang, sangatlah penting dan urgen untuk diterapkan di sekolah-sekolah.

Berdasarkan permasalahan di atas, maka penelitian ini mengkaji "peran guru didalam pembelajaran PKn dengan menggunakan model pengajaran advokasi pada siswa kelas VIII di MTs Nahdlatul Mujahidin NW Jempong Tahun Ajaran 2018/2019.

\section{B. METODE PENELITIAN}

1. Metode yang Digunakan

Metode penelitian ini menggunakan metode kualitatif, dengan pendekatandeskriptif penelitian yang bertujuan untuk mencari pemahaman dalam mengintepretasi apa yang ada dibalik peristiwa, latar belakang pemikiran manusia yang terlibat di dalamnya serta bagaimana manusia meletakkan makna pada peristiwa yang terjadi tersebut[8]. Ia juga menjelaskan penelitian deskriptif digunakan untuk berupaya memecahkan atau menjawab permasalahan yang sedang dihadapi pada situasi sekarang[9]. Dilakukan dengan langkah-langkah pengumpulan, klarisifikasi dan analisis/pengelolaan data, membuat kesimpulan dan laporan dengan tujuan utama untuk membuat gambaran tentang tentang suatu keadaan secara objektif dalam suatu deskriptif situasi. Itulah sebabnya penelitian ini akanmenggunakan metode penelitian kualitatif deskriptif.

Penelitian ini menggunakan metode kualitatif dengan pendekatan deskripitif untuk mendapatkan pemahaman untuk mengetahui tentang permasalahan yang terjadi terdalam mengenai permasalahan peran Guru PKn dalam menggunakan model pengajaran advokasi untuk meningkatkan pemahaman isu-isu sosial pada siswa kelas VIII di MTs Nahdlatul Mujahidin Nw Jempong Tahun Ajaran 2018/2019.

2. Lokasi Penelitian

Penelitian ini dilaksanakan di MTs Nahdlatul Mujahidin NW Jempong.Untuk Mata Pelajaran Pendidikan Kewarganegaraan Kelas VIII yang terletak di Jln. Adi Sucipto Jempong Ampenan Utara Kecamatan
Ampenan Kota Mataram Provinsi Nusa Tenggara Barat kode pos 83111.

3. Tehnik Penentuan Subjek Penelitian

Penelitian kualitatif tidak menggunakan populasi, karna penelitian kualitatif berangkat dari kasus tertentu yang ada pada situasi sosial tertentu dan hasil kajiannya tidak akan diberlakukan kepopulasi, tetapi ditransferkan ketempat lain pada situasi sosial yang memiliki kesamaan dengan situasi pada kasus yang dipelajari. Sampel dalam penelitian kualitatif bukan dinamakan responden tetapi sebagai narasumber, atau parsitipan, informen teman dan guru dalam penelitian.Sampel dalam penelitian kualitatif, juga bukan disebut sampel statistik, tatapi sampel teoritis, karna tujuan penelitian kualitatif adalah menghasilkan teori.Sampel dalam penelitian kualitatif disebut sebagai sampel konstruktif, karna dengan sumber data dari sampel itu dapat dikonstruksikan fenomena yang semula yang masih belum jelas[10].

Adapun yang menjadi subjek penelitian atau informan dalam penelitian ini adalah di sekolah dan pihak-pihak tertentu yang dapat memberikan data atau informasi yang dibutuhkan dalam penelitian ini, tehnik sampling yang sering digunakan adalah purposive sampling merupakan tehnik pengambilan sampel berdasarkan pada pertimbangan tertentu[11].

Berdasarkan uraian diatas dapat disimpulkan bahwa penentuan tehnik sampel yang akan digunakan dalam penelitian ini menggunakan purposive sampling. Jika data yang diperoleh tehnik ini masih kurang maka akan digunakan Snowball sampling. Digunakan purposive sampling ini karena informan ini dianggap lebih mengetahui dan lebih paham terhadap masalah yang akan diteliti dan dapat memberikan data yang lebih lengkap[12].

4. Tehnik Pengumpulan Data

Tehnik pengumpulan data adalah cara yang digunakan oleh peneliti untuk mengumpulkan data, dalam hal ini adalah proses diperolehnya data dari sumber data, sumber data yang dimaksud berasal dari subjek penelitian[8]. Dalam Penelitian ini, data yang dikumpulkan menggunakan metode sebagai berikut:

a. Metode Observasi

Observasi adalah suatu metode penggumpulan data dengan mengamati secara langsung maupun tidak langsung terhadap kegiatan-kegiatan yang sedang berlangsung. Dengan kata lain observasi adalah pengamatan yang dilakukan dengan menggunakan alat indra. Baik langsung maupun tidak langsung terhadap fakta-fakta atau gejala-gajala yang diteliti teknik observasi yang digunakan untuk membuktikan kebenaran dan informasi yang diperoleh dari dokumentasi[8].

Dari segi instrumen yang digunakan, maka observasi dapat dibedakan menjadi observasi terstruktur dan dan terstruktur antara lain[9] adalah: 
1) Observasi terstruktur

Observasi terstruktur adalah observasi yang telah dirancang secara sistematis, tentang apa yang akan diamati, dimana tempatnya, jadi, observasi terstruktur dilakukan apabila penelitian telah mengetahui dengan pasti tentang variabel yang akan diamati.

2) Observasi tidak terstruktur

Observasi tidak terstruktur adalah observasi yang tidak dipersiapkan secara sistematis tentang apa yang akan diobservasi. Hal ini dilakukan karena peneliti tidak tau pasti tentang apa yang diamati. Dalam melakukan pengamatan peneliti, peneiti tidak menggunakan instrumen yang telah baku, tetapi hanya berupa ramburambu pengamatan.

b. Metode Wawancara

Metode wawancara adalah percakapan dengan maksud tertentu. Percakapan itu dilakukan oleh dua pihak yaitu pewawancara (interview) yang mengajukan pertanyaan yang diwawancarai (interviewee) yang memberikan jawaban atas pertanyaan itu. Interview (wawancara) sebagai pertemuan dua orang untuk bertukar informasi dan ide melalui tanyajawab sehingga dapat dikonstruksikan makna dalam suatu topik tertentu[8].

Wawancara atau interview terdiri atas beberapa jenis yaitu sebagai berikut[10]:

1) Wawancara terstruktur, wawancara terstruktur adalah wawancara yang pertanyaan-pertanyaan telah disiapkan seperti menggunakan pedoman wawancara.

2) Wawancara semistruktur, wawancara semistruktur adalah wawancara yang sudah cukup mendalam karena ada penggabungan antara wawancara yang berpedoman pada pertanyaan-pertanyaan yang telah disiapkan dan pertanyaan yang lebih luas dan mendalam dan mengembalikan pedoman yang sudah ada.

3) Wawancara tidak terstruktur, wawancara tidak terstruktur adalah wawancara yang lebih bebas,lebih mendalam dan menjadikan pedoman wawancara sebagai pedoman umum dan garis-garis besarnya saja.

Sehubungan dengan penilaian ini metode wawancara yang digunakan jenis terstruktur yang digunakan untuk mengumpulkan data penelitian.

c. Metode Dokumentasi

Metode dokumentasi berasal dari kata "Dokumen" yang artinya barang-barang tertulis. Didalam melaksanakan metode dokumentasi. Peneliti menyelidiki benda-bemda tertulis seperti buku notulen rapor catatan harian, arsip, dan sebagainya. Metode dokumentasi adalah suatu metode pengambilan data dari sumber-sumber yang ditulis baik berupa surat, foto, gambar, tabel, grafik, maupun keterangan tertulis lainnya.

Dari penguraian diatas dapat diketahui bahwa tehnik dokumentasi suatu tehnik penelitian yang ditunjukkan kepada penguraian dan penjelasan terhadap apa yang telah berlangsung melalui sumber-sumber dokumen dalam mengali suatu data.

5. Metode Analisis Data

Tahap ini data dikerjakan dan dimanfaatkan sedemikian rupa sehingga dapat menyimpulkan kebenaran- kebenaran yang dapat dipakai untuk menjawab persoalan-persoalan yang diajukan dalam penelitian[8]. Pendapat lain menegaskan bahwa analisis data merupakan hal yang kritis dalam proses penelitian kualitatif[13]. Karna analisis digunakan untuk memahami hubungan dan konsep dalam data sehingga hipotesis dapat dikembangkan dan dievaluasi.

Penelitian ini menggunakan tehnik analisis data menjadi tiga macam yaitu[14];[8]:

a. Reduksi Data

Reduksi data adalah proses pemilihan, pemusatan perhatian pada penyederhanaan, pengabstraksian dan transpormasi data kasar dari cacatan tertulis selama dilapangan. Untuk mereduksi datapeneliti membuat ringkasan kontak, mengembangkan kategori, pengkodean dan membuat cacatan refleks yang bermaksud menajamkan, mengolongkan, mengarahkan yang tidak berlaku.Kemudian mengornanisasikan sedemikian rupa sehingga kesimpulan yang tepat, ini dilakukan terus-menerus selama penelitian berlangsung.

\section{b. Penyajian Data}

Penyajian data merupakan sekumpulan informasi tersusun yang memberikan kemungkinan adanya penarikan kesimpulan dan penarikan tindakan. Data teks naratif penelitian dijadikan dalam bentuk metrik, diagram, jaringan dan tabel yang dirancang peneliti untuk menggabungkan informasi dalam bentuk sederhana dan terpadu, sehingga dapat melihat dan meraskan apa yang terjadi.

\section{c. Kesimpulan atau verifikasi}

Kesimpulan atau verifikasi adalah upaya yang diperoleh selama pengumpulan data berlangsung. Penulis melakukan kesimpulan sejak awal pengumpulan data. Kesimpulan yang kurang jelas. Meningkatnya semakin rinci dan menyusun laporan final selesai. Untuk kesimpulan final peneliti terus mengadakan pengujian (verifikasi) selama penelitian berlangsung dengan berbagai cara antara lain meninjau ulang data yang ada dilapangan.

Dalam pandangan ini tiga jenis kegiatan analisis dan kegiatan pengumpulan data itu sendiri merupakan siklus dan interaktif peneliti harus siap bergerak dalam tiga hal tersebut selama pengumpulan data.Selanjutnya bergerak bolak balik diantara kegiatan reduksi, penyajian, dan penarikan kesimpulan atau verifikasi selama sisa waktu penelitian.

\section{HASIL DAN PEMBAHASAN}

\section{Peran Guru PKn dalam Menggunakan Model Pengajaran Advokasi untuk}




\section{Meningkatkan Pemahaman Isu-isu Sosial pada Siswa}

Peran guru PKn dalam menggunakan model pengajaran advokasi untuk meningkatkan pemahaman isu-isu sosial yaitu siswa memiliki moral yang baik, menjadi bertanggung jawab, disiplin, perduli dan saling menghargai. Guru PKn harus ulet dan sabar menghadapi siswa, karena tidak semua siswa memiliki sifat penuru tserta patuh. Ada beberapa siswa yang tidak patuh dan memiliki sikap acuh tak acuh terhadap gurunya. Namun semua hal di atas sedikit demi sedikit mulai teratasi karena guru PKn mampu memberikan teladan yang baik. Adapun peran guru PKn dalam model pengajaran advokasi untuk meningkatkan pemahaman isu-isu sosial yaitu :

a. Mempersiapkan perangkat pembelajaran

Setiap mengajar guru wajib mempersiapkan perangkat pembelajaran. Adapun perangkan yang disiapkan oleh guru adalah sebagai berikut:

1) Buku, yang dimana siswa harus menguasai dan membaca buku yang ada didalam sekolah Mts Nahdlatul Mujahidin NW Jempong

2) Modul yaitu siswa harus biasa memahami modul yang diberikan oleh guru didalam ruangan kelas dan juga dimana siswa dalam mengikuti pembelajaran harus ada modul yang siswa pegang agara siswa itu mengetahui ten tang pembelajaran yang mereka pelajari dalam kelas

3) Silabus adalah sebuah perangat pembelajaran yang mempunyai kegiatan inti, ada pula materi pembelajarannya

4) Media seperti yang ada di sekolah MTs Nahdlatul Mujahidin NW Jempong didalam kelas tidak menggunakan Media tetapi menggunakan Buku LKS apa yang tercantum diatas

Menurut ibu Siti Asiah selaku Kepala Sekolah MTs Nahdlatul Mujahidin NW Jempong, beliau menyatakan bahwa:

"Sikap siswa dalam melakukan belajar melalui model pengajaran advokasi ini sangat amat perlu diajarkan kepada para peserta didik MTs Nahdlatul Mujahidin NW Jempong karena pada hakikatnya manusia itu makhluk sosial yang tidak bisa hidup sendiri, manusia itu butuh pertolongan orang lain untuk memenuhi kebutuhan hidupnya. Oleh karena itu harus peduli sesame. Dalam implementasinya pendidikan atau pemahaman isu-isu sosial sebagai pendidikan sikap atau perilaku yang menuntut keteladanan di sekolah akan lebih efektif jika terdapat contoh dan keistimewahan dari para guru. Kelakuan anak yang kurang baik diperbaiki, tabiat anak yang salah dibetulkan, karena kewajiban sekolah tidak hanya sekedar mengajar akan tetapi bertanggung jawab tentang perbaikan masyarakat, kemanusiaan dan sosial. Untuk itu peran guru PKn sebagai suri tauladan dapat Membentuk generasi yang berakhlak mulia, cerdas, berbudaya, dan peduli lingkungan walaupun Hal ini tentu tidak bisa dilakukan di sekolah semaksimal mungkin, karena justru waktu peserta didik lebih banyakdi rumah dan dimasyarakat". (Wawancara, tanggal, 28 Maret 2018).

b. Memberikan Pengetahuan Keagamaan (Islam)

Kegiatan bidang keagamaan, merupakan cara efektif membina sikap sosial siswa, tingkat keagamaan siswa menjadi meningkat siswa rutinmenjalankan shalat duha, sholat zuhur bersama, melakukan yasinan dan imtak hari Jum'at dan mengikuti kegiatan hari besar keagamaan lainnya. Sedangkan kegiatan siswa dibidang sosial, yaitu bakti sosial sikap tenggang rasa dan kepedulian siswa semakin meningkat.

Seperti yang dituturkan oleh bapak Masykur sebagai guru PKn beliau menuturkan bahwa:

"Usaha yang dilakukan dalam pembelajaran ialah fokus memperhatikan kondisi siswa, mengajar seperti biasa menggunakan RPP memberi salam, motivasi, apersepsi, biasanya saya melakukan metode ceramah, diskusi, dan penilaian sesuai K13, untuk melihat sejauh mana tingkat intelektual, spiritual dan sikap siswa, misalnya menyusun indikator sikap yang sesuai dengan kompetensi yang diukur.Sikap jujur, sikap tanggung jawab, sikap percaya diri, sikap kerjasama, sikap santun atau sikap peduli." (Wawancara tanggal, 28 Maret 2018)

Konsep pemahaman isu-isu sosisl dalam Islam merupakan sistem yang paripurna yang melingkupi seluruh aspek kehidupan. MTs Nahdlatul Mujahidin NW Jempong selalu membina nilai-nilai sosial yang terkandung dalam model pengajaran advokasi, melalui proses pendidikan dan pembiasaan untuk menambah pengetahuan siswa siswi tentang agama, pihak sekolah mengadakan kegiatan Keagamaan seperti Sholat Sholat Duha, sholat Dzuhur, yasinan/ sholawatan hari Jum'at, selain kegiatan kegiatan rutin tersebut MTs Nahdlatul Mujahidin NW Jempong juga mengadakan kegiatan keagamaan seperti peringatan Maulid Nabi dan hari raya besar keagamaan Islam lainnya. siswa-siswi yang dibantu oleh para guru mengadakan tablig akbar dengan mengundang penceramah dari Sekolah, acara ini adalah acara rutin yang menjadi agenda tahunan MTs Nahdlatul Mujahidin NW Jempong.

Demikian juga menurut ibu Siti Asiah menyatakan bahwa: 
"Upaya yang dilakukan pihak sekolah dengan menciptakan kultur yang agamis.Disekolah ini mempunyai nilai tambah, walau sekolah swasta namun nuansa agamanya sangat kental sekali, sehingga kebiasaan- kebiasaan akhlaqul karimah, persaudaraan, kebersamaan, persatuan, kesetia kawanan sangat dianjurkan dengan pembiasaan.sholat duha setiap pagi sebelum masuk kelas yang, setiap hari jum'at diadakan sholawat dan yasinan, dan melalui media inilah nilai-nilai sosial dalam memahami model pengajaran advokasi yang biasa ditanamkan" (Wawancara, 28 Maret 2018).

Kegiatan Keagamaan yang diadakan di MTs Nahdlatul Mujahidin NW Jempong merupakan bentuk dari pembinaan ahlak dan bisa memahami model pengajaran advokasi untuk meningkatkan pemahaman isu-isu sosial siswa, guru harus membangun kerukunan dalam bingkai keagamaan, membina dan memupuk rasa persaudaraan, kebiasaan-kebiasaan, akhlaqul karimah, persaudaraan, kebersamaan, persatuan dan kesetiakawanan, selalu ditanamkan oleh guru PKn.

c. Memotivasi Siswa

Pendekatan secara emosional selalu dilakukan oleh guru PKn dengan memberikan nasehat dan motivasi kepada siswa baik didalam kelas maupun diluar kelas. Pembinaan sikap solidaritas sosial siswa juga dilakukan melalui kegiatan upacara, dimana Kepala Sekolah dan guru menyampaikan amanat atau menyampaikan pesan moral dan kepedulian sosial kepada siswa agar senantiasa melakukan sikap-sikap yang baik. Pemberian nasihat secara langsung menjadi salah satu cara untuk menyampaikan nilainilai kepada siswa. Siswa bisa tahu secara langsung terkait hal-hal yang boleh atau tidak boleh mereka lakukan.

Memotivasi siswa merupakan upaya guru untuk membina siswa mengetahui model pengajaran advokasi untuk meningkatkan pemahaman isu-isu sosial, motivasi sering dilakukan guru saat pembelajaran berlangsung.Selain kegiatan-kegiatan tersebut siswa dilakukan melalui kegiatan upacara, dimana Kepala Sekolah dan guru menyampaikan amanat atau menyampaikan pesan moral dan kepedulian sosial kepada siswa agar senantiasa melakukan sikap-sikap yang baik. Guru mempunyai kekuasaan untuk membentuk dan membangun kepribadiaan anak didik menjadi seorang yang berguna bagi agama, nusa, bangsa dan negara.

Menurut bapak Islahiyah selaku guru BK, motifasi diberikan kepada siswa untuk saling memperhatikan, membantu dan bekerjasama, ungkapnya:

"Sesama personal MTs Nahdlatul Mujahidin NW Jempong, harus saling memperhatikan, saling membantu dan bekerjasama baik dalam suka dan duka. Siswa siswi yang ditanamkan dan diharapkan untuk saling bekerjasama dalam hal kebaikan serta ikut membantu teman yang lemah, begitu juga antara guru dan siswa, siswa dan guru harus saling memperhatikan.Dengan harapan ada keharmonisan diantara keluarga besar MTs Nahdlatul Mujahidin NW Jempong"(Wawancara, 29 Maret 2018).

Jadi proses belajar yang dilakukan oleh guru PKn, siswa banyak mendapatkan pelajaran dan masukan tentang sikap sosial yang harus siswa miliki dengan memberikan kalimat-kalimat positif, penyemangat di awal pembelajaran PKn, bisa memberikan motivasi kepada siswa, sehingga siswa bisa berfikir dan meresapi apa yang dikatakan oleh guru. Terbentuklah di dalam hati dan diri siswa mengenai model pengajaran advokasi yang guru tanamkan, sehingga siswa akan terbiasa dan mempunyai keinginan untuk menerapkannya dalam kehidupan sehari-hari baik di rumah, di sekolah maupun di lingkungan masyarakat.

Guru sebagai pengajar, pendidikdan pembimbing maka diperlukan adanya berbagai peranan padadiriguru. Peranan guru ini akan senantiasa menggambarkan pola tingkah laku yang diharapkan dalam berbagai interaksinya, baik dengan siswa, sesama guru, maupun dengan staf yang lain.

d. Menjadi contoh teladan yang baik

Peran guru PKn dalam model pengajaran advokasi untuk meninkatkan pemahman isu-isu sosial siswa kelas VIII MTs Nahdlatul Mujahidin NW Jempongsudah baik, guru menjadi teladan bagi siwa dengan membina sikapsosial siswa antara lain, dengan memberikan bimbingan, mendidik, mengarahkan serta mencontohkan kepada siswa sikap sosial yang baik dari seorang guru, contohnya jika guru menginginkan siswa memiliki sikap disiplin, maka guru harus memberi contoh dengan disiplin pula misalnya datang ke sekolah tepat waktu. Guru juga bisa menanamkan nilai-nilai positif yang akan didapat jika siswa memiliki sikap sosial dalam diri, contohnya pentingnya sikap tolong menolong dengan sesama teman karena dengan saling tolong-menolong akan mendapatkan manfaat, seperti dapat meringankan beban orang yang telah siswa tolong, akan terjalin tali silahturahmi.

Guru bukan sekedar sosok penyampai informasi, tetapi menjadi suri teladan bagi siswanya baik itu di dalam kelas maupun di luar kelas. Sedemikian pentingnya guru memegang peranannya, sehingga guru harus bisa memanfaatkan peranannya itu dalam usaha perkembangan sikap dan kepribadiansiswa. Dalam hal ini, guru PKn menjadi salah satu faktor yang turut menentukan berhasil atau tidaknya pencapaian tujuan, yakni untuk mengembangkan potensi diri dan kepribadian anak didiknya, khususnya dalam membina sikap pemahaman isu-isu sosial siswa. 
Menurut beberapa siswa dari hasil wawancara yang peneliti peroleh, mengenai sikap guru PKn mereka sehari-hari, beberapa dari siswa menjawab bahwa guru kelas mereka memiliki sikap yang baik, sangat disiplin, tegas, bertanggungjawab, dan tidak membeda-bedakan siswa. Seperti yang diungkapkan oleh Nurul siswa kelas VIII MTs Nahdlatul Mujahidin NW Jempong, Nurul mengatakan bahwa:

"Pak Masykur itu guru yang baik, disiplin, datang ke sekolah tidak pernah terlambat, masuk kelas tepat waktu, sangat penyayang, tidak pernah membeda-bedakan siswanya, ramah, tegas, di kelas jarang ada teman- teman yang bercanda saat Pak Masykur menjelaskan materi pelajaran." (Wawancara Siswa, 29 Maret 2018)

Begitu pun menurut Baiq Amelia siswa kelas VII MTs Nahdlatul Mujahidin NW Jempong, mengatakan hal yang tidak jauh berbeda, bahwa:

"Pak Masykur itu guru yang baik, ramah, tegas dan disiplin. Pak Masykur tidak pernah malas masuk sekolah untuk mengajar.Selalu datang tepat waktu, waktu mengajar suaranya sangat keras jadi siswa termotivasi dalam belajar" (Wawancara Siswa, 29 Maret 2018)

Sikap tersebut yang patut dicontoh oleh siswa dari guru kelasnya, sikap yang patut dicontoh adalah sikap disiplin, ramah, tanggungjawab, suka menolong, sabar. dan tegas.

Untuk memahami model pengajaran advokasi kepada siswa, guru PKn harus mempunyai strategi yaitu dengan melalui pendekatan dalam kegiatan proses pembelajaran, setiap proses pembelajaran terkandung nilai-nilai karakter tertentu, begitupun diluar proses pembelajaran guru harus mampu bergaul secara efektif dan memberikan contoh sikap yang baik kepada siswa. Namun upaya untuk meningkatkan pemahaman isu-isu sosial yang dilakukan guru PKn masih mengalami kendala atau kesulitan seperti yang diungkap oleh Bapak Masykur selaku guru PKn bahwa:

"beberapa kendala yang dihadapi antara lain sikap siswa itu sendiri karna tingkat pemahaman mereka berbeda-berbeda tidak semua siswa mau belajar dan mendengar, siswa juga belum sepenuhnya menyadari bahwa dirinya sebagai makhluk sosial yang selalu akan membutuhkan pertolongan orang lain".(Wawancara, 28 Maret 2018)

Berdasarkan pendapata diatas menunjukkan bahwa guru menjadi teladan bagi siwa dengan membina sikap isu-isu sosial siswa antara lain dengan memberikan bimbingan, mendidik, mengarahkan serta mencontohkan kepada siswa untuk mengetahui model pengajaran advokasi yang baik dari seorang guru, contohnya jika guru menginginkan siswa memiliki sikap disiplin, maka guru harus memberi contoh dengan disiplin pula misalnya datang ke sekolah tepat waktu. Guru juga bisa menanamkan nilai-nilai positif yang akan didapat jika siswa memiliki sikap sosial dalam diri, contohnya pentingnya sikap tolong menolong dengan sesama teman karena dengan saling tolong-menolong akan mendapatkan manfaat, seperti dapat meringankan beban orang yang telah siswa tolong, akan terjalin tali silaturahmi, sehingga dengan upayaupaya itu siswa bisa lebih termotivasi untuk memiliki sikap solidaritas sosial yang baik.

e. Memberikan penguatan pendidikan karakter

Peran guru PKn adalah untuk membentuk siswa agar menjadi orang bersusila yang cakap, berguna bagi agama, nusa dan bangsa dimasa yang akan datang. Pengembangan pembelajaran PKn di sekolah memprioritaskan memperhatikan kualitas intelektual dan kualitas moral yang mengarah pada pembentukan watak dan kepribadian. Untuk menanamkan pemahaman isu-isu sosial pada siswa seorang guru harus mampu memberikan contoh bagi siswa-siswanya. Untuk itu seorang guru harus memiliki akhlak yang baik, karena guru adalah teladan bagi murid-muridnya.

Berdasarkan hasil wawancara dengan Bapak Masykur bahwa kepedulian siswa dalam merealisasikan model pengajaran advokasi untuk meningkatkan pemahaman isu-isu sosial yang diajarkan disekolah yaitu:

"sejauh ini menurut pengamatan saya, nilai, aturan, sikap yang diajarkan banyak dijalankan oleh siswa sehingga situasi dilingkungan sekolah terasa damai dan kondusif saya juga sering mengajarkan untuk selalu sampaikan salam, tegur sapa dan jabatangan, kesetiakawanan sosial dan saling menolong antarteman, menjenguk teman bilasakit, dan silaturahmi terutama nilai kedisiplinan". (Wawancara, 29 Maret 2018).

Guru PKn mengintegrasikan pendidikan dan pembentukan karakter, membantu anak didiknya meneruskan dan mengembangkan nilai-nilai yang hidup, mengembangkan ilmu pengetahuan dan teknologi, dan mengembangkan serta menerapkannya dalam kehidupan demi masa depan mereka.

\section{Upaya Yang dilakukan oleh Guru PKn dalam Menggunakan Model Pengajaran Advokasi Untuk Meningkatkan Pemahaman Isu-Isu Sosial pada Siswa}

Konteks pendidikan sekolah di MTs Nahdlatul Mujahidin NW Jempong yaitu, efektifitas pendidikan sosial, memahami model pengajaran advokasi terhadap siswa di sekolah peran utamanya adalah guru. 
Model pengajaran advokasi ini mempelajari tentang debat antara dua orang siswa atau dua regu kelompok untuk membicarakan permasalahan yang berkaitan dengan model pengajaran advokasi, model pengajran advokasi juga menuntut siswa untuk membahas topik yang mereka sedia didalam diskusi kelompok tersebut. Disini juga model pengajaran advokasi untuk meningkatkan pemahaman isu-isu sosial membicarakan seperti saling menolong, rasa setia kawan, bekerja sama, disiplin, jujur harus ditanamkan sejak dini.

Hasil informasi yang diuraikan beberapa narasumber, terutama Siti Asiah sebagai kepala sekolah MTs Nahdlatul Mujahidin NW Jempong upaya yagdilakukan sekolah dalam menghadapi isu-isu sosial, ia menyatakan bahwa:

"Ada beberapa cara yang sering dilakukan sekolah untuk meningkatkan pemahaman isuisu sosial dalam diri siswa, yaitu dengan melalui kegiatan belajar di sekolah, kegiatan sosial, kegiatan keagamaan seperti melakukan sholat dhuha dipagi hari yasinan bersama dihari Jum'at dan sholat dzuhur bersama sebelum pulang. Kegiatan tersebut merupakan upaya sekolah untuk meningkatkan pemahaman isuisu sosial sehingga siswa paham arti isu-isu sosial seperti berbicara sopan santun, menghargai guru dan sesama siswa,mau bergotong royong dan selain itu beliau juga berharap siswa Mengamalkan nilai-nilai agama dalam kehidupan sehari-hari". (Wawancara, 29 Maret 2018).

Senada juga pernyataan guru di MTs Nahdlatul Mujahidin NW Jempong selalu menanamkan nilai-nilai sosial, karena sekolah sangat berperan penting dalam pembentukan sikap dan nilai-nilai sosial, seperti yang diungkapkan oleh Pak Islahiyah selaku guru BK untuk saling memperhatikan, membantu dan bekerjasama, ungkapnya:

"Ya, sekolah ini sangat menganjurkan untuk mengajarkan nilai sosial. Nilai-nilai sosial itu meliputi silaturahmi, saling menyapa/memberi salam sesama teman dan guru. Rasa setia kawan, memberikan dana spontanitas kepada siswa yang mengalami musibah. Dan bakti sosial, serta kegiatan keagamaan, untuk meningkatkan pemahaman isu-isu sosialini bertujuan mendidik para siswa di sekolah agar bisa hidup rukun, damai sejahtera, di lingkungan sekolah, keluarga dan masyarakat, para siswa sukses menjalani kehidupannya di masa yang akan datang". (Wawancara, 29 Maret 2018).

Jading pendidikan dimadrasyah tersebut memiliki nilai pembeda dengan sekolah madrasyah lainn, yakni bernuansa agama sangat kental sehingga kebiasaankebiasaan akhlaqul karimah, persaudaraan, kebersamaan, persatuan dan kesetiakawanan, sangat dianjurkan dengan pembiasaan.

Berdasarkan keterangan dengan siswa kelas VIII MTs Nahdlatul Mujahidin NW Jempong mengatakan:

"Sosial di Sekolah yaitu hormat kepada guru, jangan membantah guru, patuh kepada guru, membantu teman sedang kesusahan, dan melaksanakan peraturan sekolah".

Lebih lanjut peneliti menanyakan hal apa saja yang sering dilakukan oleh siswa.

Peneliti : "Apakah kamu sering mengikuti kegiatan keagamaan?”

Siswa : Iya,sholat dan yasinan bersama hari jum.at sama sholat dzuhur sebelum pulang.

Peneliti : :Apakah Kamu selalu berbicara dengan baik terhadap temantemanmu?"

Siswa : "Iya, menggunakan Bahasa Indonesia dan sasak.

Peneliti : : "Apakah Kamu selau berbicara dengan baik terhadap guru?”

Siswa : "Iya, biasanya menggunakan Bahasa Indonesia."

Peneliti : :Apakah Kamu pernah menolong guru atau siswa lain yang membutuhkan?"

Siswa : : "iya,kalau saya lihat teman yang lagi piket saya bantu mungutin sampah."

Peneliti : "Apa yang Kamu lakukan ketika ada temanmu yang bersikap buruk terhadapmu?"

Siswa : :Lebih suka menghindari, ngga usah mbales nanti ribut lagi."

Peneliti : "Pernahkah kamu berbuatjahil terhadap guru atau siswa lain?"

Siswa : "Iya, iseng aja."

Peneliti : Apakah kamu sering mengikuti kegiatan keagamaan?

Siswa : Iya, yasinan sama acara islam seperti maulid Nabi (Wawancara, 27 Maret 2018)

Jadi siswa yang memiliki pemahaman isu-isu sosial yang baik, siswa menanggapi orang lain dengan baik hal Ini ditunjukan oleh siswa saat berkomunikasi dengan baik ketika dengan gurumaupun siswa lain. Siswa juga memiliki kemauan untuk menolong guru dan temannya yang membutuhkan.

Menurut siswa lainnya bahwa "menjaga persahabatan, menjaga kerukunan, saling memaafkan, dan saling silaturrahmi dengan sesama, dan juga tidak saling bertengkar walaupun saling berbeda-beda".

Demikian juga siswa lain diperoleh informasi sebagai berikut:

Peneliti : :pernah menjenguk teman yang sakit?” 
Siswa : : " $\quad$ :pernah, kemarin desi sakit tipes,trus aku sama teman yang lain bila, zakirin yeni, tamrin dan yang lain ngumpul uang masing dua ribu buat beli roti sama susu, baru kita jenguk samasama."

Peneliti : : "Apakah kamu pernah terlambat masuk sekolah?

Siswa : :tidak pernah, takut dimarah sama guru" (Wawancara, 29 Maret 2017)

Sementara menurut Islahiyah selaku guru BK beliau menyatakan bahwa:

"Kepedulian siswa sekolah ini sudah cukup baik, itu terlihat dari kegiatan yang kami adakan seperti sholat dhuha, dzuhur bersama, dan yasinan bersama.Siswa selalu ikut kegiatan gotong royong, membantu dan bekerjasama baik dalam suka dan duka. Begitu juga antara guru dan siswa, siswa dan guru saling memperhatikan". (Wawancara, 29 Maret 2018)

Guru harus mengarahkan dan memberikan contoh yang baik kepada siswa dan guru harus memiliki sikap tersebut agar siswa bisa mencontoh sikap dan perilaku gurunya sehingga siswa bisa meniru sikap dan perilaku guru tersebut.

\section{TEMUAN DAN DISKUSI}

Berdasarkan hasil pembahasan di atas terkait dengan peran guru PKn dalam meningkatkan pemahaman konsep siswa baik masalah social maupun masalah Negara, maka hal tersebut hasil penelitian ini menemukan bahwa peran guru dalam memberikan materi di kelas diharapkan mengacu dan menekankan pada tujuan pembelajaran mengenai implikasinya dalam kehidupan sehari-hari. Jadi tentunya guru PKn dalam membentuk karakter peserta didik memiliki peranan yang sangat penting. Karena PKn merupaka pelajaran yang bertujuan untuk membentuk warganegara yang baik dalam kehidupan sehari-hari atau dalam kehidupan berbangsa dan bernegara. Dengan demikian, peserta didik diharapkan memiliki kepribadian yang sesuai dengan nilai-nilai pancasila sehingga terciptalah generasi bangsa yang cerdas dan bermoral[15].

Demikian pula penelitian lainnya menjelaskan bahwa peran guru Pendidikan Kewarganegaraan dalam mencegah terjadinya dampak social media pada siswa yaitu: 1) Pendisiplinan secara positif akan hak anak dengan berinteraksi dengan anak dengan cara menghormati, berempati, bertoleransi, dan menghormati perbedaan, 2) Dengan menciptakan waktu berkomunikasi, kita dapat mengenal potensi timbulnya suatu masalah dan membantu anak dalam menghadapi permasalahn yang dihadapinya, 3) Menanamkan kepada siswa agar mempunyai tatakrama dan tata susila. 4) Menerapkan pendidikan karakter pada siswa[16].
MTs Nahdlatul Mujahidin NW Jempong selalu membina nilai-nilai sosial yang terkandung dalam model pengajaran advokasi, melalui proses pendidikan dan pembiasaan untuk menambah pengetahuan siswa siswi tentang agama, pihak sekolah mengadakan kegiatan Keagamaan seperti Sholat Sholat Duha, sholat Dzuhur, yasinan/ sholawatan hari Jum'at, selain kegiatan kegiatan rutin tersebut MTs Nahdlatul Mujahidin NW Jempong Juga mengadakan kegiatan keagamaan seperti peringatan Maulid Nabi dan hari raya besar keagamaan Islam lainnya. Siswa-siswi yang dibantu oleh para guru mengadakan tablig akbar dengan mengundang penceramah dari Sekolah, acara ini adalah acara rutin yang menjadi agenda tahunan MTs Nahdlatul Mujahidin NW Jempong.

Dengan demikian bahwa upaya meningkatkan pemahaman siswa terhadap isu social dengan dengan cara memberikan contoh teladan kepada siswa. Hal tersebut sesuai penelitian yang menyatakan bahwa peran guru dalam pembentukan karakter di sekolah sebagai contoh atau teladan bagi anak khususnya dan masyarakat pada umumnya. Oleh karena itu seorang guru haruslah memberi contoh yang baik, segala tingkah lakunya tidak bertentangan dengan norma dan nilai yang berlaku dimasyarakat. Segala bentuk penyimpangan tidak akan terjadi jika guru, orang tua dan masyarakat mampu memberikan teladan yang baik bagi anak, potensi untuk berbuat yang melanggar norma, aturan itu akan semakin kecil[15].

\section{E. SIMPULAN DAN SARAN}

Pertama, pelaksanaan peran guru PKn dalam menggunakan model pengajaran advokasi untuk meningkatkan pemahaman isu-isu sosial pada siswa kelas VIII di MTs Nahdlatul Mujahidin NW Jempong adalah memberikan ilmu pengetahuan, mengutamakan membina sikap sesuai nilai-nilai pancasila, melakukan pendekatan emosional kepada siswa baik dalam kelas maupun diluar kelas. Memberi contoh perilaku teladan yang baik, membiasakan datang tepat waktu, disiplin, membina siswa melakukan belajar kelompok, melakukan penilaian sikap sesuai acuan K13, memberikan motivasi, atau nasehat, rutin melakukan kegiatan sosial dan keagamaaan, seperti sholat duha, sholat dzuhur dan sholawatan/ yasinan setiap Jum'at serta aktif dalam kegiatan hari besar keagamaan islam lainnya, pembinaan sikap juga melalui upacara bendera dengan memberi motifasi dan nasehat.

Kedua, upaya yang dilakukan oleh guru didalam menggunakan model pengajaran advokasi untuk meningkatkan pemahaman isu-isu sosial pada MTs Nahdlatul Mujahidin NW Jempong yaitu, upaya yang dilakukan oleh guru dengan menciptakan pendidikan yang agamis yang mempunyai nilai tambah namun nuansa agamanya sangat kental sekali, sehingga kebiasaan-kebiasaan akhlaqul karimah, persaudaraan, 
kebersamaan, persatuan, kesetiakawanan sangat dianjurkan dengan pembiasaan dilakukan sholat dhuha setiap pagi sebelum masuk kelas yang dilangsungkan dengan do'a bersama di masjid sekolah, setiap hari Jum'at diadakan sholawat dan yasinan melalui media. Upaya melalui pembinaan ekstrakulikuler, yaitu tiap hari senin upacara bendera, pembina upacara dalam amanatnya menyisipkan pesan moral tentang kepedulian sosial, pesan-pesan moral tentang kepedulian sosial, dan tiap hari Jum'at tausiah ceramah agama yang didalamnya ada pesan-pesan moral.

Saran yang dapat disampaikan hasil ini, terutama bagi kepala sekolah untuk meningkatkan program-program sekolah yang berkaitan dengan tata tertib siswa, keteladanan guru, dan penyampaian nasehat saat upacara bendera. Bagi guru untuk lebih memperhatikan pendidikan anak, pendidikan yang tidak hanya mencerdaskan IQ saja tetapi juga pendidikan etika dan estetika agar para siswa mempunyai budi pekerti yang baik dan mempunyai sikap sosial yangtinggi.

Bagi siswa dapat menjalani proses belajar mengajar dengan tekun dan giat belajar, sehingga dapat mencapai hasil belajar yang diharapkan serta dapat lebih meningkatakan model pengajaran advokasi untuk meningkatkan pemahhaman isu-isu sosial khususnya di lingkungan sekolah. Sikap yang harus lebih ditingkatkan misalnya; 1) tidak membuat keributan di dalam kelas, 2) tepat waktu mengerjakan tugas, 3) menyukai seluruh siswa di dalamkelas. Bagi sekolah agar hendaknya meningkatkan mutu sekolah dan menyediakan fasilitas yang memadai agar mempermudah guru untuk memberikan pengajaran dalam proses belajar mengajar kepada siswa, serta bagi penelitian selanjutnya dapat mengkaji lebih lanjut mengenai pemahaman isu-isu sosial pada siswa.

\section{UCAPAN TERIMA KASIH}

Penulis mengucapkan terima kasih kepada pihak Universitas Muhammadiyah Mataram yang senantiasa memberikan saran, masukan, dan dana kepada penulis sehingga artikel ilmiah ini selesai dengan tepat waktu.

\section{DAFTAR RUJUKAN}

[1] S. Rahman, "Pengaruh Penerapan Model Pembelajaran Advokasi Terhadap Hasil Belajar Peserta Didik Pada Mata Pelajaran Sejarah Kebudayaan Islam Kelas VIII di Madrasah Tsanawiyah Al-Furqon Kecamatan Ambunten Kabupaten Sumenep.” UIN Sunan Ampel Surabaya, 2010.

[2] H. Hanafi, K. Sundara, and Z. Anshori, "Penerapan Model Pembelajaran Treffinger untuk Meningkatkan Aktifitas dan Prestasi Belajar Siswa SMP," Civicus, no. 1, pp. 11-20.

[3] B. Hasan, H. Winarti, K. Sundara, and H. Hafsah, "Pengaruh Model Pembelajaran Student Facilitator And Explining (Sfae) terhadap Hasil Belajar Siswa," Civicus, no. 1, pp. 31-37.

[4] M. Unwakoly, "Peningkatan Hasil Belajar IPS
Melalui Model Pembelajaran Advokasi Bagi Siswa Kelas III SDN Bendo 2 Kota Blitar," SKRIPSI Jur. Kependidikan Sekol. Dasar Prasekolah-Fakultas Ilmu Pendidik. UM, 2013.

[5] E. Tandililing, "Pengembangan Kemampuan Koneksi Matematissiswa Melalui Pendekatan Advokasi Dengan Penyajian Masalah OpenEnded Pada Pembelajaran Matematika," in Prosiding Seminar Nasional Matematika dan Pendidikan Matematika FMIPA UNY, 2013, vol. 9.

[6] Y. Benamen, "Penggunaan Model Pembelajaran Advokasi Untuk Peningkatan Aktivitas Dan Hasil Belajar IPS pada Siswa Kelas III SDN Madyopuro 1 Kecamatan Kedungkandang Kota Malang.," SKRIPSI Jur. Kependidikan Sekol. Dasar Prasekolah-Fakultas Ilmu Pendidik. UM, 2011.

[7] I. Rosipah, "Model Advokasi Sosial dalam Pemenuhan Hak Identitas Anak (Studi Aksesibilitas Pendidikan Anak yang Tinggal di LKSA Al-Qomariyah).” PERPUSTAKAAN, 2017.

[8] P. D. Sugiyono, "Metode Penelitian dan Pengembangan," Res. Dev. D, 2015.

[9] Sugiyono, "Metode penelitian kombinasi (mixed methods)," Bandung Alf., 2015.

[10] P. Sugiyono, Metode Penelitian Kuantitatif, Kualitatif, dan R\&D. 2013.

[11] P. Sugiyono, "Dr. 2010," Metod. Penelit. Kuantitatif, Kualitatif, dan R\&D. Bandung CV Alf.

[12] J. W. Creswell and J. D. Creswell, Research Design: Qualitative, Quantitative, and Mixed Methods Approaches. Sage publications, 2017.

[13] N. Sudjana, Belajar dan Faktor-faktor yang Mempengaruhinya. 2010.

[14] M. B. Milles, "Huberman. 1984. Qualitative Data Analysis." London: Sage Publication.

[15] F. Y. Fauzi, I. Arianto, and E. Solihatin, "Peran Guru Pendidikan Pancasila Dan Kewarganegaraan Dalam Upaya Pembentukan Karakter Peserta Didik,” J. PPKN UNJ Online,(Online), vol. 1, no. 2, 2013.

[16] S. Budiarti, "Peran Guru Pendidikan Kewarganegaraan Dalam Mencegah Terjadinya Bullying Pada Siswa (Studi kasus di SMK Muhammadiyah 1 Surakarta Tahun 2013)." Universitas Muhammadiyah Surakarta, 2013. 